JOURNAL

of Health Inequalities

\title{
An all-Poland survey of physical activity and sedentary lifestyles for middle school, high school and university students
}

\author{
Paulina Wojtyła-Buciora ${ }^{1,2}$, Tomasz Bołdowski ${ }^{3}$, Cezary Wojtyła $^{4}$, Wiola Żukiewicz-Sobczak ${ }^{5}$, \\ Katarzyna Juszczak², Maria Łabędzka-Gardy¹, Andrzej Wojtyła², Hanna Krauss ${ }^{1}$ \\ 'Department of Physiology, University of Medical Sciences, Poznan, Poland \\ ${ }^{2}$ Higher Vocational State School, Kalisz, Poland \\ ${ }^{3}$ Department of Emergency Medicine, University of Medical Sciences, Poznan, Poland \\ ${ }^{4}$ First Department of Obstetrics and Gynaecology, Centre of Postgraduate Medical Education, Warsaw, Poland \\ 5Pope John Paul II State School of Higher Education, Biala Podlaska, Poland
}

\begin{abstract}
Introduction: Most countries have witnessed an increasingly sedentary lifestyle in recent decades. Experts estimate that only one third of adolescents undertake sufficient physical activity to guarantee normal physical, mental and emotional development.

Study aims: To determine the frequency of PE (Physical Education) lessons as well as after-school movement activities and sedentary behaviour. To establish the association between physical activity, TV watching and computer use (screen time) with the risks of overweight and obesity in students.

Material and methods: A survey of 3,548 middle school students, 4,423 from high school and 5,595 university students was performed in 2011. In the former two groupings, the questionnaire had been devised by Poland's GIS (Chief Sanitary Inspectorate), based on one previously employed for WHO global school-based student health survey (GSHS) studies. The university students used an electronic questionnaire made available on an internet site from Lublin, Poland.

Results: Half the middle and high school students undertook 2 to 5 hours of physical activity per week, while only $16 \%$ of university students did so. In their free time after school, one quarter of middle and high school students engaged in selected sporting activities, usually for one hour each week. Of the university students, $84 \%$ did not undertake any movement activities at all. Excessive body mass was most frequently found in students spending 3 to 4 hours per day watching TV or using computers.

Conclusions: Students, in particular at the university level, demonstrated a somewhat poor commitment to undertaking PE lessons or other movement activities, whilst focusing mainly on sedentary activities.
\end{abstract}

KEY WORDS: overweight, obesity, physical activity, adolescents, students.

ADDRESS FOR CORRESPONDENCE: Paulina Wojtyła-Buciora, Department of Physiology, University of Medical Sciences, 6 Święcickiego Street, 60-781 Poznan, Poland, e-mail: paulinawojtyla@gmail.com

\section{INTRODUCTION}

Since the 1990s, a sedentary lifestyle has been more frequently observed in most countries, together with insufficient or nonexistent engagement in physical activities $[1,2]$. According to experts, only one third of adolescents are estimated to undertake enough physical activity to ensure normal physical, mental and emotional development [3]. A UNICEF report has demonstrated that Polish adolescents aged 11, 13 and 15 years have higher BMIs compared to adolescents from economically developed countries; with this increase doubling during 2001 to 2010 [4]. On the one hand, this trend has 
arisen from modern-day developments linked to changing lifestyles, as well as ignorance of the necessity of physical activity for normal human development.

World Health Organisation (WHO) recommendations concerning levels of physical activity in children and adolescents point out that 60-minute daily levels of 'moderate to vigorous physical activity' (MVPA) are beneficial during adolescent development $[5,6]$. In response to unsatisfactory physical activity levels in all global societies, the American College of Sports Medicine has likewise issued calls for achieving health and wellness through increasing physical activity [7]. Engaging in an active lifestyle and maintaining a normal body mass is the most effective means of preventing many modern-day diseases $[8,9]$, inter alia obesity and associated metabolic disorders, atherosclerosis [10], hypertension and cardiovascular disease [11]. Obesity is also linked to various types of cancer risk, including that of the colon, breast, endometrium, liver, kidney, oesophagus, stomach, pancreas and gall bladder [12]. Current studies show that the most effective way of dealing with obesity is through appropriate dieting and increased energy expenditure through physical activity $[13,15]$. For these reasons, educational and health programmes need to be introduced to ensure adolescents are made fully aware that physical activity and a healthy diet are required for a healthy life during all of its stages [16-18].

\section{STUDY AIMS}

1. To establish how frequently the Polish study subjects (i.e. students) took part in PE (Physical Education) lessons and after-school movement activities, and how often they opted for sedentary activities.

2. To investigate the relationship between physical activity, TV watching and time spent on computers with the risk of overweight and obesity in these subjects.

\section{STUDY METHODOLOGY}

Students selected randomly from middle schools, high schools and universities in Poland were surveyed in 2011. A total of 15,868 study subjects were chosen from 569 schools in 379 local districts. Of these, 3,548 students from middle schools, 4,423 from high schools and 7,314 from universities were qualified for statistical analyses. Roughly $78 \%$ of all respondents correctly completed their questionnaires. The number of females and males were 1,742 and 1,806 in middle school, 2,275 and 2,148 high school, and 3,315 and 2,280 at university.

Middle and high school students were asked to fill in a questionnaire which had been devised by Poland's Chief Sanitary Inspectorate (GIS) and based on previous GSHS studies (Global School-based Student Health Survey). Educational staff units of the State Sanitary Inspectorate conducted the survey. Questions concerned lifestyle behaviours.
Random sampling for the survey was performed in two stages: first by school, then by class. Subjects from the chosen classes who anonymously completed the questionnaire were enrolled for the study. These people were sampled according to randomly selected institutions taken from the Ministry of Education's database of schools registered as of 30 September 2008. The schools thus surveyed were grouped by the population of their district, the type of community (i.e. urban, rural), the province (i.e. voivodeship, there being 16 of these in Poland) and type of institution (middle school, high school, technical school). Schools were randomised using the STATISTICA 12 system. The questionnaire for university students was slightly different, in that was conducted electronically by means of a website set up by the Institute of Agricultural Medicine in Lublin. Data on types of university and each student's area of residence were collected, permitting sampling to become stratified as it was being performed, thereby allowing appropriate corrections to be made for specific groupings. Surveying the students in this way may have introduced certain systematic errors involving the reliability and completeness of responses. The correction procedure therefore used an 'over-sampling' process and excluded those questionnaires containing any errors or repetition, i.e. structural sampling adjustments were made.

In order to verify the questionnaire data, it was compared with data from Poland's Central Data Statistical Office (GUS), where significant differences were found. It was thereby decided to correct the student sampling by 'over-sampling' a relatively small portion, whereby its structure fairly closely agreed with the categories of provinces (voivodeships), gender and age as found in the nationwide GUS data. Such corrections did not remove all differences, but did make the sampling significantly more representative, essentially a compromise between representativeness and numbers. Undertaking any further corrections would have lead to further reductions in the target sample size, thus worsening the ability for testing statistical hypotheses.

The paper-based responses were entered into a central database, thus allowing for analysis by the STATISTICA 12 system. Testing the dependence of variables on a discrete scale for multi-field tables was performed by the $\chi^{2}$ test. For continuous or sequential variables, the Kruskal-Wallis test or variance analysis test was used, depending on the nature of the variable (e.g. distribution compliance). Statistical significance was taken as $p$ not greater than 0.05 .

\section{RESULTS}

The survey data gathered from middle and high school students showed they most often undertook 2 to 5 hours of PE lessons weekly, as declared by half of these subjects (Table 1). In middle and high school subjects with excessive body mass, the highest rates of overweight 
TABLE 1. Participation rates of subjects engaging in PE lessons, after-school movement activities organised by schools and their chosen sports

\begin{tabular}{|c|c|c|c|c|c|c|c|c|c|}
\hline & \multicolumn{3}{|c|}{ Physical Exercise (PE) lessons } & \multicolumn{3}{|c|}{$\begin{array}{l}\text { After-school movement } \\
\text { activities organised at school }\end{array}$} & \multicolumn{3}{|c|}{ Engaging in chosen sports } \\
\hline & $\begin{array}{l}\text { Middle } \\
\text { school }\end{array}$ & $\begin{array}{l}\text { High } \\
\text { school }\end{array}$ & University & $\begin{array}{l}\text { Middle } \\
\text { school }\end{array}$ & $\begin{array}{l}\text { High } \\
\text { school }\end{array}$ & University & $\begin{array}{l}\text { Middle } \\
\text { school }\end{array}$ & $\begin{array}{l}\text { High } \\
\text { school }\end{array}$ & University \\
\hline & $N=3541$ & $N=4416$ & $N=5588$ & $N=3541$ & $N=4416$ & $N=5588$ & $N=3541$ & $N=4416$ & $N=5588$ \\
\hline \multirow{2}{*}{$\begin{array}{l}\text { Not } \\
\text { applicable }\end{array}$} & 169 & 356 & 3024 & 1896 & 2870 & 4718 & 552 & 995 & 1960 \\
\hline & $5 \%$ & $8 \%$ & $54 \%$ & $54 \%$ & $65 \%$ & $84 \%$ & $16 \%$ & $23 \%$ & $35 \%$ \\
\hline \multirow{2}{*}{$\begin{array}{l}\text { Up } \\
\text { to } 1 \mathrm{~h}\end{array}$} & 463 & 396 & 353 & 522 & 522 & 281 & 877 & 1109 & 1200 \\
\hline & $13 \%$ & $9 \%$ & $7 \%$ & $15 \%$ & $12 \%$ & $5 \%$ & $25 \%$ & $25 \%$ & $21 \%$ \\
\hline \multirow[t]{2}{*}{$1-2 \mathrm{~h}$} & 663 & 1047 & 1177 & 644 & 561 & 302 & 871 & 896 & 965 \\
\hline & $19 \%$ & $24 \%$ & $21 \%$ & $18 \%$ & $13 \%$ & $5 \%$ & $24 \%$ & $20 \%$ & $17 \%$ \\
\hline \multirow[t]{2}{*}{$2-5 \mathrm{~h}$} & 1830 & 2313 & 914 & 331 & 292 & 163 & 611 & 695 & 825 \\
\hline & $52 \%$ & $52 \%$ & $16 \%$ & $9 \%$ & $6 \%$ & $3 \%$ & $17 \%$ & $16 \%$ & $15 \%$ \\
\hline \multirow[t]{2}{*}{ 5-7 h } & 265 & 183 & 52 & 63 & 86 & 39 & 273 & 348 & 269 \\
\hline & $7 \%$ & $4 \%$ & $1 \%$ & $2 \%$ & $2 \%$ & $1 \%$ & $8 \%$ & $8 \%$ & $5 \%$ \\
\hline \multirow[t]{2}{*}{$>7 \mathrm{~h}$} & 151 & 121 & 68 & 85 & 85 & 85 & 357 & 373 & 369 \\
\hline & $4 \%$ & $3 \%$ & $1 \%$ & $2 \%$ & $2 \%$ & $2 \%$ & $10 \%$ & $8 \%$ & $7 \%$ \\
\hline$p ;\left(\chi^{2}\right)$ & \multicolumn{3}{|c|}{$<0.001$} & \multicolumn{3}{|c|}{$<0.001$} & \multicolumn{3}{|c|}{$<0.001$} \\
\hline
\end{tabular}

and obesity were observed for those engaging in only 1 to 2 hours of physical activity per week (Table 2). University students demonstrated a greater unwillingness to take part in any obligatory PE lessons compared to their younger counterparts, with $54 \%$ declaring no participation whatsoever (Table 1). The highest rates of overweight and obesity occurred in those students spending only one hour per week on movement activities (Table 2).

This study demonstrated that normal body mass was dependent on frequency of participation in PE. The highest rates of optimal BMI were observed for those engaging in 5 to 7 hours of physical exercise weekly (Table 2). A decided majority of respondents did not take part in any extra after-school activities. Answers from the younger students on how frequently they engaged in defined sports were found to be unsatisfactory. In their free time, every fourth student from middle or high school spent one hour a week on a chosen sport (Table 1). This attests to a weak commitment in adolescents to engaging in movement activities, both at and after school. University students most often spent their free time with peers. It was however satisfying that subjects spent even five hours per week on movement and games. It was also found that $35 \%$ and $33 \%$ of middle and high school students, respectively, helped their parents with domestic chores. Even so, such help was limited to 1 to 2 hours weekly (Table 3 ).

Sedentary behaviour increases with age. This is supported by our study, where $54 \%$ of university students participated in no PE lessons. Furthermore, up to $84 \%$ did no extra movement activities organised by their insti- tutions. In their free time, 35\% abstained from doing any sport (Table 1), and on a weekly basis, half the subjects took no part at all in any games or movement activities with their peers. Similarly to their younger counterparts, $28 \%$ of these students most often devoted 1 to 2 hours per week to domestic chores (Table 3).

Subjects were asked how they most often commuted to school and how much time this took. This significantly affected estimates of their daily physical activity. Walking to school was undertaken by $41 \%, 36 \%$ and $25 \%$ of middle school, high school and university students, $p\left(\chi^{2}\right)<$ 0.001 . Correspondingly, $82 \%, 65 \%$ and $43 \%$ declared that commuting to school took 20 minutes (Fig. 1.). Subjects most often commuted to school by public transport, at rates of $41 \%, 46 \%$ and $45 \%$, respectively. Commuting by bicycle was not popular, with only $5 \%, 3 \%$ and $1 \%$ doing so, $p\left(\chi^{2}\right)<0.001$. More time was decidedly spent on activities associated with less energy expenditure, as demonstrated by commuting time being most often one hour per week (Table 3). More than a third of subjects in each grouping most frequently spent their free time watching TV or being on computers (Fig. 2).

It was often seen that overweight and obesity rates were directly related to increases in the time spent watching TV and being on computers. This was observed for each age grouping. Of those middle school (13\%), high school (14\%) and university (14\%) students who were overweight, it was observed that $6 \%, 5 \%$ and $6 \%$ with excessive body mass most often spent 5 to 6 hours per day watching TV or being on computers. The corresponding obesity rates for spending this amount of time 
on such sedentary activities were $2 \%, 1 \%$ and $2 \%$. The highest rates of subjects with normal BMI were those who spent two hours daily watching TV or being on computers (Table 4).

\section{DISCUSSION}

Like adults, adolescents increasingly demonstrate low levels of physical activity. This leads to higher rates of overweight and obesity, which in turn increase the risk of modern-day diseases. A 2013 HSBC study (Health Behaviour in School-Aged Children) conducted in Poland, showed that the recommended daily levels of one hour's physical activity was achieved by only $28 \%$ of adolescents aged 11 to 12 years, $23 \%$ of those aged 13 to 14 and $13 \%$ in the 15 to 17 age group [19]. A study conducted in north-east Brazil on secondary schoolchildren aged 14 to 19 years, demonstrated that only $50 \%$ of subjects took part in PE lessons totaling over 300 minutes per week [20]. Different means of commuting to school influence overall activity levels [21, 22]. This all-Poland study shows that public transport dominates in this respect. It is estimated that it takes around 20 minutes for students to travel to school. Those commuting on foot constitute $41 \%, 36 \%$ and $25 \%$ of middle school, high school and university students, respectively. Only $5 \%, 5 \%$ and $1 \%$ opt to commute by bicycle. The HBSC study showed a journey time of 15 minutes in $60 \%$ of subjects, with the majority (47\%) walking to school. Like our survey, the HSBC study showed a low rate $(5 \%)$ of commuting by bicycle [19].

For the majority of children and adolescents, PE lessons at school constitute their only organised means of engaging in physical activity. Many international organisations for physical activity, and UNESCO, argue that physical education is an integral part of schooling and should be mandatory for at least one hour daily for all students [23]. In Poland, PE lessons are obligatory for a total of four hours weekly for elementary and middle school students and three hours for older students [24].

This study has demonstrated that only half of middle and high school students take part in PE lessons for 2 to 5 hours weekly. The Brazilian study on students aged 14 to 19 years shows only $35 \%$ engaging regularly in PE lessons [25]. Woynarowska found that almost every third pupil abstains from all or nearly all PE lessons [26]. In order for the needs of children to be satisfied in terms of performing regular physical activity at school, a diverse choice of such activities should be offered and tailored to the child's stage of development, especially at the youngest ages.

An important part of overall physical activity is having a diversity of movement and sporting activities chosen freely by students apart from PE lessons. This nationwide study found that every fourth middle and high school subject is engaged in a sport during their free time for one hour weekly, whereas every fifth subject

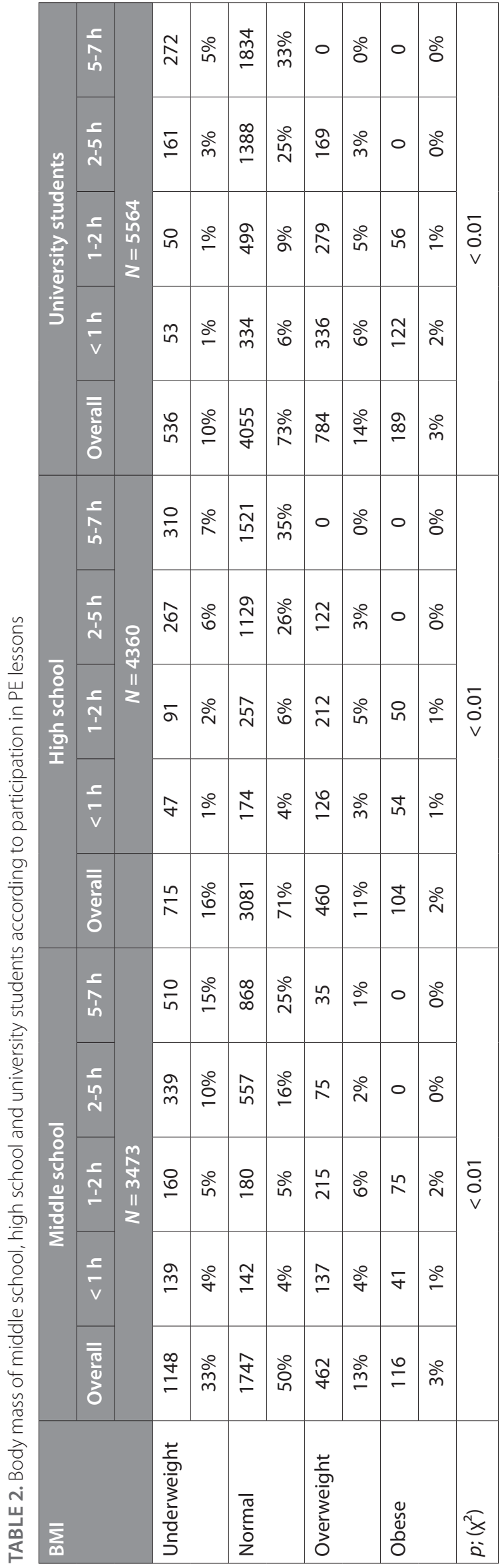


TABLE 3. Participation rates of subjects engaging in weekly movement activities linked to commuting, participating in games and movement games with their peers along with helping with domestic chores

\begin{tabular}{|c|c|c|c|c|c|c|c|c|c|}
\hline & \multicolumn{3}{|c|}{$\begin{array}{l}\text { Activities linked to commuting } \\
\text { to and from school }\end{array}$} & \multicolumn{3}{|c|}{$\begin{array}{l}\text { Games and movement games } \\
\text { with peers }\end{array}$} & \multicolumn{3}{|c|}{ Helping with domestic chores } \\
\hline & $\begin{array}{l}\text { Middle } \\
\text { school }\end{array}$ & $\begin{array}{l}\text { High } \\
\text { school }\end{array}$ & University & $\begin{array}{l}\text { Middle } \\
\text { school }\end{array}$ & $\begin{array}{l}\text { High } \\
\text { school }\end{array}$ & University & $\begin{array}{l}\text { Middle } \\
\text { school }\end{array}$ & $\begin{array}{l}\text { High } \\
\text { school }\end{array}$ & University \\
\hline & $N=3541$ & $N=4416$ & $N=5588$ & $N=3541$ & $N=4416$ & $N=5588$ & $N=3541$ & $N=4416$ & $N=5588$ \\
\hline \multirow{2}{*}{$\begin{array}{l}\text { Not } \\
\text { applicable }\end{array}$} & 568 & 563 & 952 & 319 & 791 & 2781 & 274 & 358 & 482 \\
\hline & $16 \%$ & $13 \%$ & $17 \%$ & $9 \%$ & $18 \%$ & $50 \%$ & $8 \%$ & $8 \%$ & $8 \%$ \\
\hline \multirow[t]{2}{*}{ Up to $1 \mathrm{~h}$} & 1893 & 2208 & 2132 & 694 & 1071 & 1172 & 1075 & 1027 & 1329 \\
\hline & $54 \%$ & $50 \%$ & $38 \%$ & $20 \%$ & $24 \%$ & $21 \%$ & $30 \%$ & $23 \%$ & $23 \%$ \\
\hline \multirow[t]{2}{*}{$1-2 \mathrm{~h}$} & 537 & 797 & 1060 & 1044 & 1095 & 841 & 1231 & 1457 & 1585 \\
\hline & $15 \%$ & $18 \%$ & $19 \%$ & $29 \%$ & $25 \%$ & $15 \%$ & $35 \%$ & $33 \%$ & $28 \%$ \\
\hline \multirow[t]{2}{*}{$2-5 \mathrm{~h}$} & 332 & 443 & 781 & 897 & 880 & 534 & 657 & 1049 & 1394 \\
\hline & $9 \%$ & $10 \%$ & $14 \%$ & $25 \%$ & $20 \%$ & $9 \%$ & $18 \%$ & $24 \%$ & $25 \%$ \\
\hline \multirow[t]{2}{*}{ 5-7 h } & 133 & 230 & 296 & 283 & 283 & 115 & 178 & 286 & 391 \\
\hline & $4 \%$ & $5 \%$ & $5 \%$ & $8 \%$ & $6 \%$ & $2 \%$ & $5 \%$ & $7 \%$ & $7 \%$ \\
\hline \multirow[t]{2}{*}{$>7 \mathrm{~h}$} & 78 & 175 & 367 & 304 & 296 & 145 & 126 & 239 & 407 \\
\hline & $2 \%$ & $4 \%$ & $7 \%$ & $9 \%$ & $7 \%$ & $3 \%$ & $4 \%$ & $5 \%$ & $9 \%$ \\
\hline$p ;\left(\chi^{2}\right)$ & \multicolumn{3}{|c|}{$<0.001$} & \multicolumn{3}{|c|}{$<0.001$} & \multicolumn{3}{|c|}{$<0.001$} \\
\hline
\end{tabular}

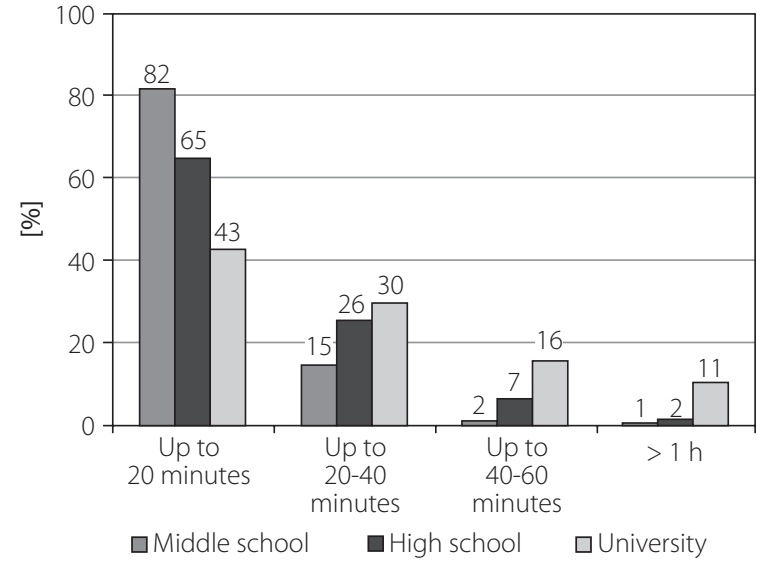

FIG. 1. Subject's daily commuting time to school, $p\left(\chi^{2}\right)<0.001$

never did this at all. Indeed, GUS data confirm our findings, where $30 \%$ of elementary schoolchildren undertake at least one hour of physical activity weekly [27]. During free time however, physical activity was not a popular option. In the majority of children, movement activities were limited to obligatory PE at school, which is itself inadequate. Nevertheless, it is encouraging to see that $25 \%$ and $20 \%$ of middle and high school students engage up to five hours weekly in games and movement games in the company of their peers. Furthermore, every third of these students does two hours of domestic chores per week.

As they mature, young people are less physically active. Our study shows that $54 \%$ of students do not take

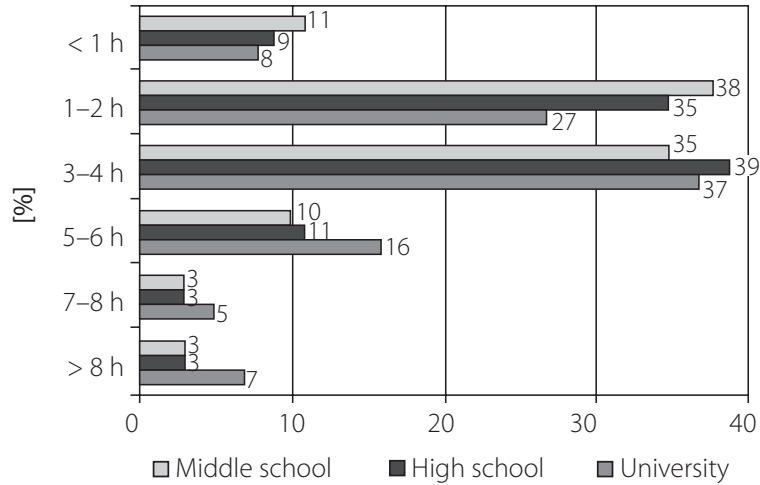

FIG.2. Daily time spent (hours) watching TV or being on computers

part in PE lessons, 84\% abstain from after-school movement activities and 35\% never undertake any sports at all. When comparing the free time university students actively spend with their peers, they diverge from the younger subjects of our study, and most frequently (15\%) spend 1 to 2 hours weekly on chosen physical activities in the company of their peers. They also willingly help with domestic chores.

Subjects preferred spending 3 to 4 hours per day watching TV or being on the computer as opposed to engaging in sports or other forms of physical activities. This was observed in 35\%,39\% and 37\% of middle school, high school and university students. Numerous international recommendations stress that sedentary activities (e.g. 'screen time') should be confined to two hours daily $[28,29]$. Studies conducted from 2002 to 2010 in 30 
selected countries showed that watching TV declined only slightly. The largest decreases in weekday and weekend viewing were seen in males from the Ukraine, Latvia, Estonia, Russia, Norway and the US. For females, the greatest differences were observed in Finland, Norway, Ukraine, Wales, Estonia, Italy, Latvia, Spain and the US. Nonetheless, there has been a massive rise in computer use by both females and males in all the surveyed countries [30]. Brazilian studies show that $69 \%$ of teenagers spend weekday time watching TV and being on computers, whilst $80 \%$ do so at weekends [31]. Similar studies on Polish and Czech secondary school students have likewise found that more time is spent on screen time at weekends compared to weekdays [32]. A survey by Jodkowska on Polish 13-year-olds demonstrated that the most free time is spent watching TV, followed by being on the computer, jointly amounting to four hours per schoolday and six hours daily at weekends [33]. Our work has also shown that time spent on sedentary activities is closely related to how parents supervise their children; more supervision corresponds to less screen time. Furthermore, Fenner has demonstrated that those overweight teenagers motivated by their parents to pursue an active lifestyle do indeed engage in more physical activity [34].

Shortfalls in physical activity constitute an independent risk factor for obesity [35]. A Chilean study on teenagers showed that those who were obese and spent excessive time watching TV and being on computers ( $\geq$ 2 hours daily) had low levels of physical activity [36]. A Brazilian survey of teens 14 to 17 years old found that overweight rates were directly related to low levels of physical activity and increased screen time [37]. This is confirmed by our study, where the highest rates of overweight and obesity were observed in students who abstained from PE lessons and indulged in 5 to 6 hours per day of screen time. US studies on secondary school students showed that subjects spent at least 5 hours per day watching TV, which was linked to increased obesity [38]. A study from Cracow on middle schoolers who spent excessive time surfing the Internet found that $7 \%$ had become addicted to the practice [39]. An interesting solution is to take advantage of both the Internet's popularity and its usefulness as a source of educational knowledge concerning healthy lifestyles, as has been exploited by Park et al. [4]. By such means, these researchers developed a 'Teen-Friendly Health Education Program' available on social media and networking service 'Facebook'. Thus, by exploiting the benefits of the Internet, suitable texts can be promoted to help teenagers make informed choices for adopting healthy lifestyles.

\section{CONCLUSIONS}

Students, especially at university, are somewhat poorly committed to doing PE lessons and other forms of movement activities, preferring to engage in mainly sedentary activities.

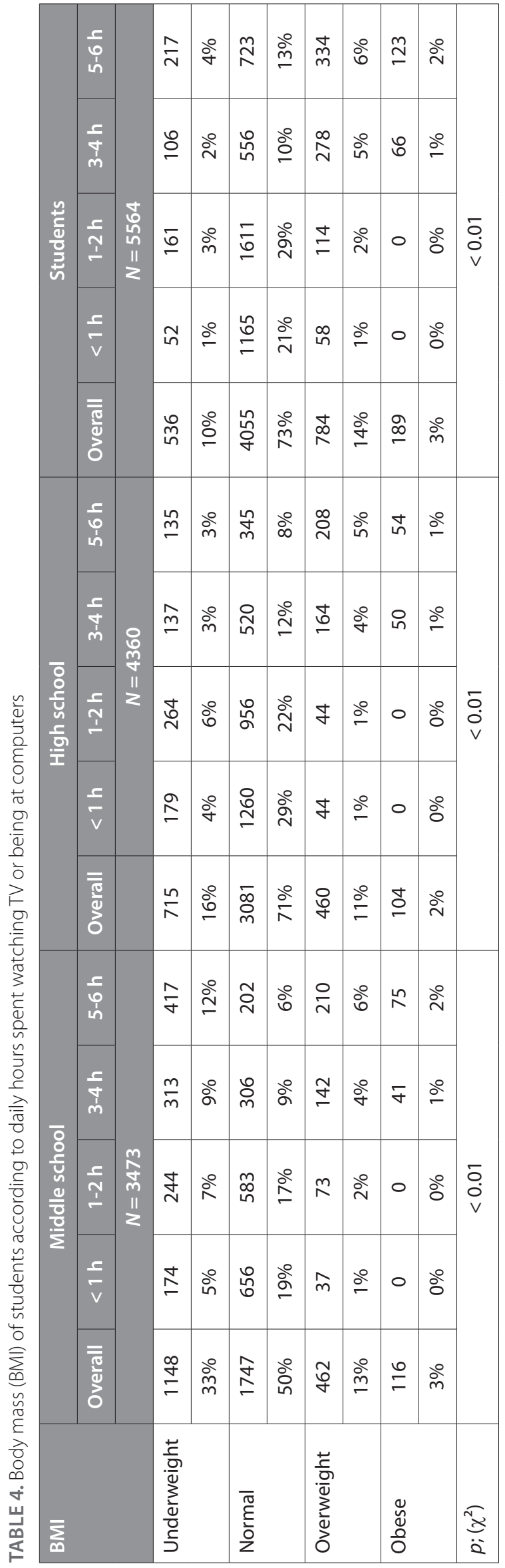


Increased overweight and obesity rates found in subjects are directly related to engaging in physical activity less frequently, but also to increased hours spent watching $\mathrm{TV}$ and being on computers.

\section{ACKNOWLEDGEMENTS}

Editors would like to acknowledge the invaluable assistance of Mr. Scott Thompson in the preparation of the final version of this article.

\section{DISCLOSURE}

Authors report no conflict of interest.

\section{References}

1. Bassett DR, John D, Conger SA, et al. Trends in physical activity and sedentary behaviors of United States youth. J Phys Act Health 2015; 12: 1102-1111.

2. Guinhouya BC. Physical activity of schoolchildren in France. The paradox of a public health priority! Rev Epidemiol Sante Publique 2010; 58: 255-267.

3. Kantomaa MT, Tammelin TH, Demakakos P, et al. Physical activity, emotional and behavioural problems, maternal education and self-reported educational performance of adolescents. Health Educ Res 2010; 25: 368-379.

4. UNICEF Office of Research. Warunki i jakość życia dzieci w krajach rozwiniętych [Conditions and quality of life of children in countries developed]. Analiza porównawcza, Innocenti Report Card 11, UNICEF Office of Research, Florencja 2013. Available from: https://www.unicef.pl/content/download/12107/116935/ file/Warunki\%20i\%20jako\%C5\%9B\%C4\%87\%20\%C5\%BCycia\%20dzieci\%20w\%20krajach\%20rozwini\%C4\%99tych.pdf (accessed: 1 May 2017).

5. Janssen I, Leblanc AG. Systematic review of the health benefits of physical activity and fitness in school-aged children and youth. Int J Behav Nutr Phys Act 2010; 7: 40.

6. Global recommendations on physical activity for health Availablefrom:http://www.who.int/dietphysicalactivity/pa/en/ (accessed: 1 May 2017)

7. Garber CE, Blissmer B, Deschenes MR, et al. American College of Sports Medicine position stand. Quantity and quality of exercise for developing and maintaining cardiorespiratory, musculoskeletal, and neuromotor fitness in apparently healthy adults: guidance for prescribing exercise. Med Sci Sports Exerc 2011; 43: 1334-1359.

8. Sliwa SA, Sharma S, Dietz WH, et al. Healthy kids out of school: using mixed methods to dvelop principles for promoting healthy eating andphysical activity in out-of-school settings in the United States. Prev Chronic Dis 2014; 11: E227.

9. Story M, Nanney MS, Schwartz MB. Schools and obesity prevention: creating school environments and policies to promote healthy eating and physical activity. Milbank Q 2009; 87: 71-100.

10. Michalska A, Bylina D, Czeczuk A, et al. Selected atherosclerosis risk factors in youth aged 13-15 years. Postepy Hig Med Dosw 2012; 66: 647-654.
11. Twig G, Yaniv G, Levine H, et al. Body-Mass Index in 2.3 Million Adolescents and Cardiovascular Death in Adulthood. N Engl J Med 2016; 374: 2430-2440.

12. Tahergorabi Z, Khazaei M, Moodi M, Chamani E. From obesity to cancer: a review on proposed mechanisms. Cell Biochem Funct 2016; 34, 533-545.

13. Wojtyła-Buciora P, Marcinkowski JT. Aktywność fizyczna w opinii młodzieży licealnej i ich rodziców [The opinion of high school students and their parents concerning physical activity]. Probl Hig Epidemiol 2010, 91: 644-649.

14. Suliburska J, Bogdanski P, Pupek-Musialik D, et al. Analysis of lifestyle of young adults in the rural and urban areas. Ann Agric Environ Med 2012; 19: 135-139.

15. Wojtyła-Buciora P, Stawińska-Witoszyńska B, Wojtyła K, et al. Assessing physical and sedentary lifestyle behaviours for children and adolescents living in a district of Poland; What are the key determinants to improving health. Ann Agric Environ Med 2014; 21: 606-612.

16. Wojtyła-Buciora P, Bołdowski T, Wojtyła C, et al. The "Keep Fit!" programme for building health-competence in children and adolescents in Poland regarding their diet and physical activity - study design. J Health Inequal 2016; 2: 172-177.

17. Topalidau A, Dafopoulou GM. Obesity prevention for junior high school students: an intervention programme. J Phys Educ Sport 2013; 13: 147-152

18. Wojtyła-Buciora P, Bołdowski T, Wojtyła C, et al. National survey of body mass and dietary behaviour for middle school, high school and university students. J Health Inequal 2017; 3: 1-6.

19. Mazur J, Oblacińska A, Jodkowska M, et al. Aktywność fizyczna młodzieży szkolnej w wieku 9-17 lat. Aktualne wskaźniki, tendencje ich zmian oraz wybrane zewnętrzne i wewnętrzne uwarunkowania [Physical activity of schoolchildren aged 9-17 years. Current indicators, trends in their changes, and selected external and internal determinants]. Available from: https:// s3-eu-west 1.amazonaws.com/fs.siteor.com/msport/files/badania\%20i\%20analizy/dzieci/aktywnosc_9-17_ilosciowy. pdf?1438846009 (accessed: 1 May 2017)

20. Farias Júnior JC, Lopes Ada S, Mota J, Hallal PC. Physical activity practice and associated factors in adolescents in Northeastern Brazil. Rev Saude Publica 2012; 46: 505-515.

21. Carson V, Kuhle S, Spence JC, Veugelers PJ. Parents' perception of neighbourhood environment as a determinant of screen time, physical activity and active transport. Can J Public Health 2010; 101: 124-127.

22. Cooper AR, Jago R, Southward EF, Page AS. Active travel and physical activity across the school transition: the PEACH project. Med Sci Sports Exerc 2012; 44: 1890-1897.

23. Onofre M, Marques AR, Moreira R, et al. Physical education and sport in Europe: from individual reality to collective desirability (Part 1). Intern J Physical Educ 2012; 49: 31-35.

24. Rozporządzenie Ministra Edukacji Narodowej z dnia 7 lutego 2012 r. w sprawie ramowych planów nauczania w szkołach publicznych (Dz.U. z 2012 r. poz. 204 ze zm.) [Regulation of the Minister of National Education of 7 February 2012 on the framework of teaching plans in public schools]. Available from: 
http://isap.sejm.gov.pl/DetailsServlet?id=WDU20120000204 (accessed: 1 May 2017).

25. Santos SJ, Hardman CM, Barros SS, et al. Association between physical activity, participation in Physical Education classes, and social isolation in adolescents. J Pediatr (Rio J) 2015; 91: 543-550.

26. Woynarowska B, Mazur J, Oblacińska A. Participation of students in physical education lessons in schools in Poland. Hygeia Public Health 2015; 50: 183-190.

27. Główny Urząd Statystyczny: Zdrowie ludności i młodzieży w Polsce w 2009 r. [Central Statistical Office: Health of the population and youth in Poland in 2009]. Kraków 2011. Available from: http://stat.gov.pl/cps/rde/xbcr/gus/zo_zdrowie_dzieci_ mlodziezy_w_polsce_2009.pdf (accessed: 1 May 2017).

28. Tremblay MS, Leblanc AG, Janssen I, et al. Canadian sedentary behaviour guidelines for children and youth. Appl Physiol Nutr Metab 2011; 36: 59-71.

29. Australian Government Department of Health. Australia's Physical Activity \& Sedentary Behaviour Guidelines for Children (5-12 years) 2014. Available from: http://www.health. gov.au/internet/main/publishing.nsf/content/health-pubhlthstrateg-phys-act-guidelines\#apa512 (accessed: 1 May 2017).

30. Bucksch J, Sigmundova D, Hamrik Z, et al. International trends in adolescent screen-time behaviors from 2002 to 2010. J Adolesc Health 2016; 58: 417-425.

31. Ferreira RW, Rombaldi AJ, Ricardo LI, et al. Prevalence of sedentary behavior and its correlates among primary and secondary school students. Rev Paul Pediatr 2016; 34: 56-63.

32. Frömel K, Kudlacek M, Groffik D, et al. Differences in the intensity of physical activity during school days and weekends in Polish and Czech boys and girls. Ann Agric Environ Med 2016; 23: 357-260.

33. Jodkowska M, Tabak I, Oblacińska A, Stalmach M. Sedentary behaviour 13-year-olds and its association with selected health behaviours, parenting practices and body mass. Med Wieku Rozwoj 2013; 17: 165-173.

34. Kipp LE. Psychosocial aspects of youth physical activity. Pediatr Exerc Sci 2017; 29: 35-38.

35. Chung AE, Skinner AC, Steiner MJ, Perrin EM. Physical activity and BMI in a nationally representative sample of children and adolescents. Clin Pediatr (Phila) 2012; 51: 122-129.

36. García-Hermoso A, Marina R. Relationship of weight status, physical activity and screen time with academic achievement in adolescents. Obes Res Clin Pract 2017; 11: 44-50.

37. Boynton-Jarrett R, Thomas TN, Peterson KE, et al. Impact of television viewing patterns on fruit and vegetable consumption among adolescents. Pediatrics 2003; 112: 1321-1326.

38. Kenney EL, Gortmaker SL. United States adolescents' television, computer, videogame, smartphone, and tablet use: associations with sugary drinks, sleep, physical activity, and obesity. J Pediatr 2017; 182: 144-149.

39. Średniawa A, Jarczewska DŁ, Żabicka K, et al. Internet addiction among graduates of general secondary schools in Cracow and its correlation with body mass index and other health problems. Pol Merkur Lekarski 2015; 39: 31-36.
40. Park BK, Nahm ES, Rogers VE. Development of a Teen-Friendly Health Education Program on Facebook: lessons learned. J Pediatr Health Care 2015. pii: S0891-5245(15)00226-6.

\section{AUTHORS' CONTRIBUTIONS}

PWB, WŻS, AW prepared the research concept and design of the publication. TB, WŻŚ, MŁG and KJ collected data. PWB, TB, KW, MŁG and $\mathrm{KJ}$ analysed data. PWB and CW wrote the article. AW critically reviewed the publication. HK finally approved the publication. 